\title{
The Exodus and the spade: The impact of archaeology on the interpretation of the book of Exodus
}

\author{
H L Bosman \\ University of Stellenbosch
}

\begin{abstract}
The interpretation of the book of Exodus is used as an example of the different ways in which archaeological discoveries influenced the course of biblical exegesis. Special emphasis will be placed on matters such as the Amarna letters and the Habiru, Merneptah Stele and the date of the Exodus and the Egyptian background of the Exodus. In conclusion it will be argued that critical dialogue and mutual respect must exist between archaeology and biblical studies. The theological interpretation of biblical texts is inevitably an interdisciplinary endeavor and archaeology is an academic discipline that must be part of the critical dialogue with biblical exegesis.
\end{abstract}

\section{INTRODUCTION}

Few scholars would dispute the importance of archaeology for the interpretation of the Bible, but even less will agree how to go about it.

On the one hand George Mendenhall (1978:28) is not optimistic about any meaningful dialogue between archaeology and theology. He categorically states: "Between theology and archaeology there is a gulf fixed; so great a gulf is it that in comparison the two cultures of C P Snow seem but rivulets, minor tributaries in the canyon of academia." On the other hand one is confronted by the $19^{\text {th }}$ century point of view as articulated by Eisenlohr (1872:355). "It has long been the object of Egyptologists to discover in the numerous Egyptian monuments still remaining in stone and papyrus, traces of the Israelites, which might show us the events related in the Old 
Testament from an Egyptian point of view." This view is still perpetuated in latter day fundamentalist interpretations of the Bible.

Sir Mortimer Wheeler once remarked that archaeology does not dig up artifacts but people - that is, the remains of material culture. An important element of frustration in the dialogue between archaeology and biblical studies has been the absence of any trace of Israel as a people in Egypt during the Late Bronze or Early Iron Age.

The interpretation of the book of Exodus provides a good example of the different ways in which archaeological discoveries have influenced the course of biblical exegesis. It might seem foolhardy to some Old Testament scholars to attempt any historical reconstruction of Israel's stay in and departure from Egypt - with or without archaeology (Miller \& Hayes 1986:79). But theologians tend to rush in where historians and archaeologists fear to tread!

\section{A SURVEY OF RECENT COMMENTARIES ON EXODUS}

In this paper a number of commentaries on Exodus published during the last three decades will be used to illustrate the influence of archaeology on the theological interpretation of the book of Exodus.

- Fensham (1970) published his commentary in Dutch in a series that concentrated on exegesis that is considered useful for preaching. Although Fensham, as a former student of W F Albright felt himself at home in the so called "Baltimore School" which paid special attention to the verifying role of "Biblical archaeology" in exegesis, he does not spend much time to discuss archaeological matters. Probably not due to lack of interest, but due to the restrictions imposed on him by the POT commentary series.

- Hyatt (1971) wrote his commentary as an attempt to integrate the then emerging tradition-historical interpretation of Exodus with its existing source and form analysis. It is clear through out the commentary that Hyatt remains in two minds about the historicity of Exodus. "The book of Exodus should not be read as if it were primarily a historical record" (Hyatt 1971:37), while on the very next page: "Nevertheless, the 
book of Exodus professes to be history, and its narrative undoubtedly rests upon a solid core of historical happening" (Hyatt 1971:38). In the final analysis he acknowledges that scholars "cannot reconstruct all the details of the exodus from Egypt, but that the general outline in the book of Exodus is credible" (Hyatt 1971: 44).

- In one of the best biblical commentaries ever written, Childs (1974) gave attention to source and form-critical questions, paid attention to tradition-historical approaches, did pioneering work to consider the Jewish and Christian exegesis throughout the ages. Despite the broad canvass of the history of interpretation, he ignored almost all of the geographical and historical questions and concentrated on the final "form of the text." Childs (1974:229) devoted some of his "Detailed Notes" to historical questions related to the Exodus, without going into any detail and by and large accepting the broad archaeological or historical consensus with regards to a particular problem.

- An even more voluminous commentary by Schmidt (1988) commenced with remarks very much in the traditional historical-critical mould. Although little new ground has been broken, Schmidt has succeeded in compiling a valuable survey of source-, literary-, form- and, traditional critical; as well as geographical and historical research. In general Schmidt (1988:37) seems to be cautious to come to a generalized conclusion: "So kann man wohl nur allgemein feststellen, dass eine israelitische Gruppe - wahrscheinlich im Zuge der aramäischen Wanderungswelle - für einen nicht eindeutig angebbaren Zeitraum im Ostdelta sesshaft wurde.”

- Durham (1987) has written an excellent commentary which was more circumspect about historical matters, than many of his theologically conservative predecessors. He appreciates studies by van Seters, Greenberg, Herrmann and Nicholson who "established beyond cavil what may be called the contextual plausibility of the Exodus narrative without confirming the historicity of even one of its events or personages" (Durham 1987:xxv). Despite the lack of historical confirmation, he does qualify his statement: "This is not of course to say that the events and persons referred 
to by Exodus are not historical, only that we have no historical proof of them (Durham 1987:xvi).

- Houtman (1993) wrote a well documented and carefully argued commentary with ample attention to matters historical. In the almost 20 pages on the topic "The book of Israel and history", he states clearly in the introductory paragraph: "For information about Israel's arrival in Egypt, its stay there and its departure from it, the only source we have is the Bible" (Houtman 1993:172). After discussing the different opinions about the historicity of the Exodus he links the discussion about the Exodus with the other thorny issue about the settlement in Palestine. He then comes to the following conclusion (Houtman 1993:179):

There can be no question that there is a tie between the manner in which the archaeological data are handled and one's assessment of the biblical givens. The knowledge gained from archaeological excavations has not resulted in a consensus about the date and nature of Israel's settlement in Canaan ... These diverse views are possible because, historically speaking, the archaeological data lend themselves to a variety of interpretations and because no precise picture of the history emerges from them...In brief, it is impossible to determine the date of the exodus and to construct a picture of the Israel of the exodus only with the use of data derived from the archaeology of Palestine.

In the final paragraph of his discussion he anticipates a hypothetical scenario in which it was possible to arrive at a precise reconstruction of Israel's early history in Egypt and Palestine where the historical reliability of Exodus is verified by the history of the ancient Near East. Even then he concludes" (Houtman 1993:190): it still does not prove that YHWH revealed himself to Moses and entered into a covenant with Israel ... Accepting that is a matter of faith. That faith is not dependent on outside proof and reconstructions of the history." Houtman is quite adamant that it is not the task of the exegete to suggest historical reconstructions of Israel's past, but does explain that it is the exegete's responsibility to explain and clarify the picture the author aims to 
give." How this is possible without "historical reconstruction", Houtman unfortunately fails to explain!

- Janzen (1997) wrote a theologically stimulating and creative commentary to inform ministers in preaching and pastoral activity, but no mention is made about historical questions and the influence archaeology has in this regard.

- Nearer to home, Ashby (1998) wrote a short but insightful commentary with as title: "Go out and meet God." For him the commentator of Exodus must start with its theology and not with its historicity. One of the reasons for this point of departure is: "The actual historical details, though important to those of us with a Western training and background, have a low priority in the story as a whole" (Ashby 1998:62).

- The most recent commentary on Exodus is only partly finished by Propp (1999). Although reference is made to textual criticism, source and redactional analyses, the bulk of the commentary is made up by "notes" (technical matters of interpretation) and "comments" (more general or extended discussions). We will have to wait for the publication of volume II in which Appendix B will address "the date and historicity of Israel's departure from Egypt ... matters of chronology and geography, and how the Egyptian tradition squares with contemporary archaeology's picture of emergent Israel" (Propp 1999:53-54). An innovation Propp (1999:54) is rightly proud of is "labeling extreme lines of conjecture Speculation." The reason for this innovation is both serious and tongue in the cheek: "Controlled fantasy is relatively benign, and indeed it prepares us for future discoveries. Speculation is harmful only when it parades as certainty" (Propp 1999:54).

The book of Exodus has not lacked good commentaries during the past three decades and they reflect some of the best (and worst?) research on the Old Testament/Hebrew Bible. It seems as if the demise of the Biblical Theology movement, with the closely related Baltimore school of theological interpretation (Albright, Wright and Bright), and the 
replacement of "biblical" archaeology with "new" archaeology, led to a more cautious understanding of the historicity of the Bible and the Exodus in particular.

Let us now turn to a few of problems with regards to the historicity of the Exodus as perceived by archaeology and historians of the ancient Near East.

\section{SOME PROBLEMS REGARDING THE HISTORICITY OF THE EXODUS}

\subsection{The Amarna Letters and the ápiru/habiru}

Archaeological record seems to indicate population shifts and socio-economical changes in Palestine at the end of the Late Bronze Age and the beginning of the Iron Age (Miller 1996:65-67). The discovery of more than 350 Akkadian cuneiform diplomatic letters at el-Amarna in 1887 provided information about Palestine in the Late Bronze Age (late $15^{\text {th }}$ and early $14^{\text {th }}$ centuries BCE) and mention is made of nomadic groups called the habiru. Due to a similarity in spelling a number of scholars identified the habiru with the “Íbri/hebrews” (Ash 1999:320).

In the Amarna letter from Abdu-Heba of Jerusalem the following reference is made of the Habiru/Apiru (ANET 487-488): "The Ápiru plunder all the lands of the king."

Some confusion and difference of opinion exist about the relationship of the apiru/habiru (marauding bandits) and the Shasu/Sutu (nomadic pastoralists) synonymous terms in Egyptian and Akkadian texts respectively (Lemche 1998:68-69). Malamat (1998:85) suggested the 'apiru was connected to the Hebrews, ruling out the Shasu, but also cautioning: "Although every Israelite is a Hebrew and likely an ápiru, not every Hebrew or Ápiru is necessarily an Israelite". Johnstone (1990:26) denies any evidence of Arameaean wanderers that reached the Nile delta and according to him "the Egyptian records speak rather of the Shosu, the bedouin population of the Sinai peninsula." 


\subsection{The Merneptah Stele and the date of the Exodus}

Soon after WF Petrie discovered the Merneptah Stele in 1887, the earliest extra-biblical reference to "Israel" was translated. When Petrie learned about the content of the translation and its reference to Israel, he remarked: "Won't the reverends be pleased!" (Shanks 1997:36).

On the basis of the inscription on the Merneptah Stele, many scholars accept the presence of Israel in Palestine at the start of the Iron Age (about 1200 BCE). But is this as simple and clear cut as many scholars would like us believe?

The Merneptah Stele was a 2.3 meter, black granite monolith; discovered amongst the ruins of Merneptah's funerary temple in Thebes (Yurco 1991:58). This stele was inscribed about 1207 BCE and it commemorates pharaoh Merneptah's victories over the Libyans and the Sea Peoples. In the hymnic conclusion of the inscription the following claims are made (ANET 378):

Desolation is for Tehenu; Hatti is pacified;

Plundered is the Canaan with every evil;

Carried off is Ashkelon; seized upon is Gezer;

Yanoam is made as that which does not exist;

Israel is laid waste, his seed is not;

Hurru is become a widow for Egypt!

All lands together, they are pacified;

Everyone who is restless, he has been bound.

In the inscription the name "Israel" is preceded by a hieroglyphic sign that normally refers to a people and not to a region (Canaan) or a city (Ashkelon and Gezer). Thus, it seems as if the inscription "testifies to the existence of a population group, bearing the name 'Israel' ...living in Canaan" during the $13^{\text {th }}$ century BCE (Miller \& Hayes 1986:68).

Ahlstrom, in his book "Who were the Israelites", has a different interpretation of the Merneptah inscription. He contends that "Israel" was a geographic term that designated the central hill country of Palestine and ethnic or cultural designation. Coote argues that one should not take for granted that the Israel on the stele was the cultural 
entity with the same name that we came to know in the Bible. The Israel of the stele was simply a Palestinian tribe or tribal confederation.

\subsection{The Egyptian background to the Exodus}

During a conference held at Brown University in 1992, Abraham Malamat delivered a paper "The Exodus: Egyptian analogies" in which he argues for a connection between the exodus and different analogies drawn from the $19^{\text {th }}$ dynasty in Egypt (Frerichs 1997). Although analogies do not amount to historical proof, one can take note of the similarities Malamat referred to:

- the correspondence between the use of a foreign labor force for state building projects by Rameses II and the exodus story;

- the reference to run-away slaves being pursued by an Egyptian owner as described in Anastasi Papyrus V as explanation for the vast Hebrew migration from Egypt and the subsequent hot pursuit by pharaoh in the biblical narrative;

- the troubled times at the end of the $19^{\text {th }}$ dynasty during which there was civil strife with opposing sides hiring Asiatic mercenaries who, when they were defeated, were expelled from Egypt; and

- the period of about 20 to 30 years from the death of Merneptah to the rise of Sethnacht and the $20^{\text {th }}$ dynasty when the royal chancellor Bay, a "Syrian", played the role of a kingmaker. Bay or Bey is also identified by de Moor, even in the latest edition of his "The rise of Yahwism", with Moses.

James Hoffmeier (1997:226) comes to a similar conclusion after he reviewed much of the indirect or circumstancial evidence: "the main points of the Israel in Egypt and exodus narratives are indeed plausible".

After suggesting that the "exodus is a post-Exilic composition", even Donald Redford (1987:150) (a staunch critic of the maximalist position) is not willing to brand "the Biblical tradition as a wholly late fabrication.". Redford (1987:150) comes to the following conclusion with which Hoffmeier (1997:226) is in broad agreement - only differing in deriving the exodus from the Hyksos experience: 
- There was an early and strong reminiscence of a voluntary descent into Egypt by pastoralists in which one Jacob played a leading part, and was later to achieve a reputation as an ancestral figure;

- Those who made a descent had not only prospered and multiplied, but had also for a time become exceedingly influential in Egypt;

- Subsequently, strong antipathy had risen between the authocthonous inhabitants and the Asiatic newcomers; and

- This had resulted in the enforced retirement of the intrusive element to the Levantine littoral (from) which they had emerged.

\section{CONCLUSION}

In conclusion it will be argued that rigorous critical dialogue and mutual respect must exist between archaeology and biblical studies. The theological interpretation of biblical texts is inevitably an interdisciplinary endeavor and archaeology is one of the academic disciplines that must be part of the critical dialogue with biblical exegesis.

To my mind theological exegesis should be allowed to interpret the Exodus narrative as a medium for expressing theological and religious traditions. This theological interpretation must however remember that: "the historical events in Exodus are not the source but the vehicle, not the proof but the proving-ground (Johnstone 1990: 36).

Perhaps a dialogue between archaeology and biblical exegesis can be facilitated by a redefinition (again!) of "biblical archaeology" as "the archaeology of the ancient Near East in the biblical period". Biblical Archaeology must be recognized as a part of biblical studies that in an interdisciplinary way scrutinize "the pertinent results of archaeological research to elucidate the historical by and cultural setting of the Bible" (Dever 1997:318). Biblical studies can not move beyond a Sitz im Literatur to an informed Sitz im Leben without archaeology providing the cultural and material context, as mediated through a redefined biblical archaeology.

Although archaeology is not "mute" without texts, biblical scholarship can still contribute new voices from the biblical texts that remain important literature from Iron Age Palestine. Archaeology can "contribute to questions related to faith and morality, 
although not by offering 'proofs'... archaeology illuminates, but cannot confirm; it brings understanding, but not necessarily belief" (Dever 1997: 319).

\section{Works consulted}

Ash, P S 1999. Egyptology and Biblical studies, in Hayes, J H (ed), Dictionary of Biblical Interpretation A-J, 318-323. Nashville: Abingdon.

Ashby, G 1998. Go out and meet God: A commentary on the book of Exodus. Grand Rapids: Eerdmans. (ITC.)

Childs, B S 1978. Exodus. London: SCM. (OTL.)

Currid, J D 1997. Ancient Egypt and the Old Testament. Grand Rapids: Baker Books.

Durham, J I 1987. Exodus. Waco: Word Books. (Word.)

Eisenlohr, A 1872. On the political condition of Egypt before the reign of Rameses III. Transactions of the Society of Biblical Archaeology 1, 355.

Fensham, F C 1970. Exodus. Nijkerk: Callenbach. (POT.)

Hoffmeier, J K 1997. Israel in Egypt: The evidence for the authenticity of the Exodus tradition. New York: Oxford University Press.

Houtman, C 1993. Exodus, I. Kampen: Kok. (HCOT.)

Hyatt, J P 1971. Exodus. Grand Rapids: Eerdmans. (NCB.)

Janzen, J G 1997. Exodus. Louisville: Westminster/John Knox. (WBC.)

Johnstone, W 1990. Exodus. Sheffield: JSOT Press. (OT Guides.)

Knauf, E A 2000. The "low chronology" and how not to deal with it. BN 101, 56-63.

Lemche, N P 1998. The Israelites in history and tradition. London: SPCK.

Mendenhall, G E 1978. Between theology and archaeology. JSOT 7, 28-34.

Miller, J M \& Hayes, J H 1986. A history of ancient Israel and Judah. Philadelphia: Westminster.

Miller, J M 1996. Introduction to the history of ancient Israel, in The New Interpreter's Bible. Louisville: Abingdon

Noth, M 1962. Exodus. London: SCM. (OTL.)

Propp, W H C 1998. Exodus 1-18. New York: Doubleday. (AB.) 
Redford, D 1987. An Egyptological perspective on the Exodus narratives, in Rainey, A F (ed), Egypts, Israel, Sinai: Archaeological and historical relationships in the biblical period. Tell Aviv: Tel Aviv University Press.

Schmidt, W H 1988. Exodus. Neukirchen-Vluyn: Neukirchener Verlag. (BKAT II/1.)

Shanks, H 1997. The biblical minimalists: Expunging ancient Israel's past. Bible Review $13,32-50$.

Stiebing, W H (jr) 1989. Out of the desert? Archcaeology and the exodus/conquest narratives. Buffalo: Prometheus Books. 